\title{
MEMBANGUN KESADARAN HUKUM DAN PEMENUHAN HAK-HAK PEREMPUAN DI NEGERI SEILALE
}

\author{
Yonna Beatrix Salamor ${ }^{1}$, Anna Maria Salamor ${ }^{2}$ \\ ${ }^{1,2)}$ Program Studi Ilmu Hukum, Fakultas Hukum, Universitas Pattimura \\ e-mail: yonnahukum@gmail.com
}

\begin{abstract}
Abstrak
Masyarakat abad 21 yang telah memasuki era kemajuan ilmu pengetahuan dan teknologi serta wacana penegakan hak asasi manusia (HAM) yang telah berkembang masih menyisahkan perbedaan antara perempuan dan laki-laki. Menomor duakan perempuan sebagai second making decision, membuat kedudukan perempuan masih jauh tertinggal dibandingkan dengan laki-laki. Dalam berbagai segi, perempuan sebagai orang kedua, pemenuhan hak-hak perempuan diabaikan. Hal ini juga dirasakan bagi perempuan dan anak perempuan di Negeri Seilale, kecamatan Nusaniwe, Kota Ambon. Tingginya perkawinan dibawah umur bagi perempuan, rendahnya tingkat Pendidikan bagi anak perempuan, serta kekerasan yang sering diterima oleh perempuan-perempuan di negeri Seilale, menjadi latarbelakang dilaksanakan kegiatan pengabdian masyarakat ini. Metode yang digunakan dalam pengabdian masyarakat ini yaitu penyuluhan serta konseling hukum bagi perempuan dan anak perempuan di Negeri Seilale. Kami berharap kegiatan ini dapat memberikan dampak yang positif dengan berkurangnya tindak kekerasan, persamaan pendidikan, dan persamaan pendapat bagi perempuan dan laki-laki di desa Seilale.
\end{abstract}

Kata Kunci: Kesadaran Hukum, Perempuan, Seilale

\begin{abstract}
21st century society that has entered the era of advancement of science and technology and the discourse of enforcement of human rights (HAM) has developed still separates the differences between women and men. Putting women as the second making decision, making position of women still far behind compared to men. In many ways, women as second persons, the fulfillment of women's rights are ignored. This was also felt for women and girls in the village of Seilale, District of Nusaniwe, City of Ambon. The high number of underage marriages for women, the low level of education for girls, as well as the violence that is often accepted by women in the village of Sagea, are the background of these community service activities. The method used in this community service is counseling and legal counseling for women and girls in the village of Seilale. We hope that this activity can have a positive impact by reducing violence, reducing the number of girls dropping out of school and equality of opinion for women and men in the village of Seilale.
\end{abstract}

Keywords: Legal Awareness, Women, Seilale.

\section{PENDAHULUAN}

Seilale sebagai salah satu desa yang terletak di semenanjung Nusaniwe dan berselebelahan dengan negeri Latuhalat dengan penduduk lebih dari 1.000 jiwa, menyimpan berbagai masalah yang salah satunya adalah perempuan. Tidak dapat dipungkiri, meskipun masyarakat abad 21 ini sudah memasuki era globalisasi dan wacana penegakan Hak Asasi Manusia (HAM) sudah sedemikian berkembang, namun menyangkut stigmatitasi terhadap seksualitas perempuan, tampaknya masih kuat berakar dalam budaya masyarakat. Pandangan yang dikotomis tersebut pada akhirnya membuat perempuan tidak mudah untuk mengakses hak-haknya, baik ketika masyarakat maupun aparat memosisikannya sebagai korban. Perempuan dan anak adalah objek yang sangat rentan menjadi korban kekerasan. Perempuan menjadi objek pengebirian dan pelecehan hak-haknya. Perempuan tidak berdaya menghadapi kebiadaban individual, cultural dan structural yang dibenarkan. Nilai-nilai kesusilaan yang seharusnya dijaga 
kesuciannya dikoyak. Kekerasan, pelecehan dan eksploitasi seksual bukan hanya menimpa perempuan dewasa akan tetapi juga anak (Hehanussa, Deassy J. \& Salamor, Y, 2019). Rendahnya tingkat pendidikan yang diberikan kepada anak perempuan membuat perempuan dan anak perempuan di desa Sagea masih dinomorduakan. Dalam masyarakat, persamaan hak antara perempuan dan laki-laki di Desa Sagea tidak dilaksanakan dengan baik. Perempuan masih ditempatkan sebagai pembantu pengambilan keputusan (second making decision).

Pada dasarnya hak tentang perempuan telah diatur dalam The Convention On The Elimination Of All Forms Of Discrimination Against Women (CEDAW). CEDAW atau ICEDAW (International Convention on Elimination of All Forms of Discrimation Against Women) adalah sebuah Kesepakatan Hak Asasi Internasional yang secara khusus mengatur hak-hak perempuan . Konvensi ini mendefinisikan prinsip prinsip tentang hak hak manusia, norma-norma dan standar-standar kelakuan dan kewajiban dimana Negara-negara peserta konvensi sepakat untuk memenuhinya.

Konvensi ini juga bicara tentang penghapusan segala bentuk diskriminasi terhadap perempuan yang memungkinkan setiap individu/kelompok yang tidak puas atas pelaksanaan CEDAW di negaranya dapat mengajukan langsung permasalahannya kepada pemerintah bahkan sampai PBB. Indonesia adalah salah satu negara yang ikut menandatanganinya. Adapun hak perempuan yang diatur meliputi:

1. Hak dalam ketenagakerjaan

2. Hak dalam bidang kesehatan

3. Hak yang sama dalam pendidikan

4. Hak dalam perkawinan dan keluarga

5. Hak dalam kehidupan publik dan politik.

Kurangnya kesadaran masyarkat khususnya perempuan terhadap haknya, menyebabkan perempuan Sagea tidak dapat menikmati hak dengan baik. Tingkat pendidikan yang rendah, perkawinan diusia yang muda, dan tidak dapat menyampaikan pendapat di depan umum adalah beberapa masalah pokok yang dialami oleh perempuan dan anak perempuan di Negeri Seilale. Oleh karena itu, kegiatan pengabdian masyarakat ini kami lakukan sebagai salah satu bagian Tri Dharma sekaligus untuk mengedukasi perempuan Seilale terhadap kesadaran hukum dan haknya.

\section{METODE}

Kegiatan pengabdian masyarakat yang dilaksanakan di Negeri Seilale dilakukan dengan menggunakan metode pendidikan masyarakat. Salah satu bentuk metode pendidikan masyarakat yang digunakan antara lain dengan melakukan penyuluhan dan konseling hukum. Penyuluhan hukum dilakukan setelah sebelumnya dilakukan identifikasi permasalahan yang terjadi di Negeri Seilale. Penyuluhan hukum ini diharapkan dapat meningkatkan kesadaran hukum masyarakat, khususnya perempuan dan anak perempuan tentang haknya, serta mengurangi diskriminasi yang terjadi antara perempuan dan laki-laki. Sedangkan konseling hukum, dilakukan terhadap perempuan dan anak perempuan yang sedang menghadapi masalah atau berhadapan dengan hukum dengan mempergunakan pendekatan kekeluargaan dan hukum.

\section{HASIL DAN PEMBAHASAN}

Konvensi Penghapusan Segala Bentuk Diskriminasi Terhadap Wanita (Convention on the Elimination of Discrimination Against Women/CEDAW) adalah instrumen internasional yang merupakan salah satu Konvensi Hak Asasi Manusia. Melalui perjalanan panjang sejak dicetuskannya Konferensi PBB sedunia tentang Perempuan I di Mexico City, perjuangan kaum perempuan untuk mendapat perlakuan yang sama dengan kaum laki-laki disahkan oleh PBB, pada tahun 1979.

Secara juridis (de jure) hak-hak perempuan di bidang, ekonomi, sosial, budaya, sipil dan politik yang menjadi substansi dari Konvensi CEDAW, telah diakui dunia internasional termasuk Indonesia yang telah 
meratifikasi Konvensi tsb pada tahun 1984 dan sekaligus berkewajiban untuk melaksanakannya. Setelah disahkannya Konvensi CEDAW, pertemuan kaum perempuan sedunia dilanjutkan dalam Konferensi Perempuan II tahun 1980 di Kopenhagen, III di Nairobi pada tahun 1985 dan tahun 1995 yang IV di Beijing. Perjuangan kaum perempuan serta aktivis perempuan sedunia terus aktif dalam mengikuti perkembangan dunia dengan mengikuti pertemuan-pertemuan internasional, seperti Konfrensi PBB tentang Lingkungan Hidup di Rio de Janeiro tahun 1992, Hak Asasi Manusia tahun 1993, Kependudukan dan Pembangunan di Kairo tahun 1994 dan pertemuan internasional lainnya.

Marginalisasi perempuan yang muncul kemudian menunjukkan bahwa perempuan menjadi the second sex (warga kelas dua) yang keberadaaannya tidak begitu diperhitungkan. bentuk ketidakadilan gender yang berupa proses marginalisasi perempuan adalah suatu proses pemiskinan atas satu jenis kelamin tertentu dalam hal ini perempuan disebabkan oleh perbedaan gender. Ada beberapa perbedaan jenis dan bentuk, tempat dan waktu serta mekanisme proses marginalisasi perempuan karena perbedaan gender. Dari aspek sumber misalnya, marginalisasi atau pemiskinan perempuan dapat bersumber dari kebijakan pemerintah, keyakinan, tafsir agama, tradisi atau kebiasaan, bahkan asumsi ilmu pengetahuan (Nina, J., 2012).

Di Negeri Seilale, sebagian besar perempuan berprofesi sebagai penjual ikan (jibu-jibu). Keadaan ini terjadi karena, penghasilan suami yang tidak mencukupi, rendahnya tingkat pendidikan perempuan seilale sehingga membuat mereka lebih banyak mengambil profesi/pekerjaan sebagai penjual ikan di pasar. Tidak jarang, kekerasan diterima oleh perempuan dan anak perempuan di negeri Seilale. Hak-hak mereka tidak diperhitungkan, sehingga banyak dari jumlah keseluruhan perempuan Seilale yang hanya berpendidikan tamat SD dan SMP.

Kegiatan penyuluhan dan konsultasi hukum ini dilakukan dengan melibatkan perempuan GPM, AMGPM Ranting Seilale serta pemerintah negeri. Didahului dengan identifikasi masalah-masalah yang dihadapi perempuan dan anak perempuan di negeri Seilale. Kegiatan penyuluhan dilakukan dilakukan selama 2 jam, yang berisikan pemaparan dan proses edukasi hak-hak perempuan dan anak perempuan. Dalam sesi penyuluhan ini, banyak masalah yang muncul sebagai respon dari para peserta penyuluhan. Dari sekian banyak pertanyaan yang didalamnya dibumbuhi dengan permasalahan yang dihadapi, dapat disimpulkan kurangnya pemahaman tentang hak perempuan karena rendahnya tingkat pendidikan menjadi faktor yang paling dominan.

Pada sesi konseling hukum untuk perempuan, sebagian besar masalah yang ditemui sebagai keluhan adalah masalah kekerasan, baik kekerasan dalam rumah tangga maupun kekerasan selama proses pacaran. Kekerasan yang paling banyak berupa kekerasan fisik dan verbal, yang bila dicermati kemudian dianggap sebagai sebuah bagian yang WAJAR dalam pernikahan atau hubungan pacaran.

\section{SIMPULAN}

Rendahnya tingkat pendidikan serta kurangnya akses terhadap hak perempuan merupakan faktor yang mempengaruhi kesadaran hukum dan hak terhadap perempuan di Negeri Seilale. Oleh karena itu, banyak terjadi kekerasan baik secara fisik maupun verbal terhadap perempuan di negeri Seilale.

\section{SARAN}

Kami berharap dengan adanya penyuluhan dan konseling hukum bagi perempuan dan anak perempuan di Negeria Seilale dapat memberikan pemahanan tentang hak mereka sebagai perempuan serta memberikan kesadaran hukum dalam hidup bermasyarakat sehingga kekerasan yang terjadi dapat dicegah dan dihindari.

\section{UCAPAN TERIMA KASIH}

Pemerintah Negeri Seilale

AMGPM Ranting Seilale

Fakultas Hukum Universitas Pattimura 


\section{DAFTAR PUSTAKA}

Gultom, M. (2018). Perlindungan Hukum Terhadap Anak dan Perempuan. Bandung: PT. Refika Aditama. Nina, Johan. (2012). Perempuan Naulu: Tradisionalisme dan Kultur Patriarki. Jakarta: Yayasan Pustaka Obor Indonesia.

SAbitri, N. (2008). HAM Perempuan: Kritik Teori Hukum Feminis Terhadap KUHP. Bandung: PT. Refika Aditama.

Hehanussa, Deassy J.A., \& Salamor, Yonna B. (2019). Membangun Kesadaran Hukum Bagi Perempuan dan Anak Dalam Penanggulangan Tindak Pidana Kekerasan Seksual. SABDAMAS: Prosiding Universitas Atma Jaya., 1 (1). 293-297. 